\title{
Application of comet assay for determination of genotoxicity of veterinary vaccines preparations
}

\author{
S. M. Dybkova, I. E. Roman'ko', T. G. Gruzina, L. S. Rieznichenko, Z. R. Ulberg, V. \\ O. Ushkalov', A. M. Golovko
}

Institute of Biocolloid Chemistry by F.D. Ovcharenko of National Academy of Sciences of Ukraine Acadimic Vernadsky Boulevard, 42, Kyiv, Ukraine, 03142;

1 - National Scientific Center "Institute of Experimental and Clinic Veterinary Medicine" of Ukrainian Academy of Agrarian Sciences Pushkinska str., 83, Kharkiv, Ukraine, 61023;

2 - State Scientific and Control Institute of Biotechnology and Microorganism Strains Donetska str., 30, Kyiv, Ukraine, 03151

tgruzina@mail.ru

\begin{abstract}
Aim. To study a possibility of usage of the alkaline gel electrophoresis method (Comet assay) for determination of genotoxic properties of veterinary vaccines preparations. Methods. The alkaline gel-electrophoresis of isolated eukaryotic cells has been used with further visualization of the samples by fluorescent microscopy. Results. Veterinary vaccines testing by the Comet assay method under alkaline conditions revealed that the samples No.1 and No 12 from twelve investigated vaccine preparations had genotoxic influence on eukaryotic cells of $\mathrm{CHO}-\mathrm{K} 1$ and Vero test cultures, No. 12 sample being genotoxic only at metabolic activation. Conclusions. The method of alkaline gel electrophoresis of single cells (Comet assay) is suitable for determination of veterinary vaccines genotoxic influence on the test eukaryotic cells $\mathrm{CHO}-\mathrm{K} 1$. The method proposed in this paper is express, inexpensive and predictive. The accomplished experimental work allows us to recommend this method for characterization of biosafety of veterinary vaccines preparations.
\end{abstract}

Keywords: genotoxicity, veterinary vaccines, cells culture, method of alkaline single cells gel electrophoresis, biosafety.

Introduction. Veterinary vaccines are the remedies that prevent development of many hazardous and severe animal diseases such as leptospirosis, rabies, plague etc. Practical veterinary medicine possesses a wide set of commercial preparations of veterinary vaccines manufactured by various firms. Taking into consideration the necessity of maintenance of pure-bred animal genomes and production of biologically safe animal raw material, it is imperative

(C) Institute of Molecular Biology and Genetics NAS of Ukraine, 2010 to elaborate an express method for assessment of genotoxicity of such preparations.

Among well-known methods of genotoxicity evaluation the assay of alkaline gel-electrophoresis of isolated cells (DNA Comet assay) is accepted as the most suitable one [1-8] due to its high sensitivity at the level of individual cells, high predictability and possibility to evaluate the level of pathogenetical primary lesions of DNA without considering mutations. 
The level of DNA lesions of tested eukaryotic cells serves as an indicator for this method. The method is based on registration of the mobility] of cell culture DNA and its possible fragments, treated with the tested substance and then immobilized in agarose gel, and subjected to lysis. Moving in a constant electric field to the anode, DNA forms an electrophoretic track that looks like a "comet tail" with the parameters depending on the level of DNA lesions. DNA Comet assay in the alkaline modification allows to register the single strand breaks (SSB) and alkaline-labile sites. This significantly increases informativeness of the method.

Our work is aimed to study the possibilities of alkaline gel-electrophoresis method (DNA Comet assay) for determination of genotoxic properties of veterinary vaccines.

Material and methods. Tris- $\mathrm{HCl}, 0.5$ and $1 \%$ agarose solutions were obtained from Serva (Germany), acridine orange, N-nitrosomethylurea, tripan blue were purchased from Sigma (USA). All other chemicals were of analytical grade and produced in Ukraine.

Experiments were performed in two parallels.

Vaccine preparations of various producers, well-known in veterinary practice, were also used. Below there is a list of studied veterinary vaccines:

No 1 - against leptospirosis;

No 2 - against avian rinovirus;

No 3 - against plague of carnivorous, adenovirus infections, parvovirus and coronavirus canine enteritis;

No 4 - against canine leptospirosis and rabies;

No 5 - live lyophilized vaccine against avian infectious bronchitis;

No 6 - inactivated vaccine against animal rabies;

No 7 - inactivated vaccine against canine rabies and leptospirosis;

No 8 - live lyophilized vaccine against feline panleucopenia, herpes and caliciviral infections;

No 9 - against plague of carnivorous, canine adenovirosis, parvovirosis, paragrip and leptosirosis;

No 10 - live vaccine against feline herpes virus and calicivirus infections;

No 11 - live lyophilized vaccine against chicken pneumovirus infection;

No 12 - inactivated vaccine against feline microspore infection.
Cell cultures, namely CHO-K1 - cell culture of Chinese hamster ovary, Vero - cell culture of African green monkey kidney, obtained from the collection of State Scientific and Control Institute of Biotechnology and Microorganism Strains (Ukraine), were used as the tested cells.

Cells of both CHO-K1 and Vero lines were cultivated in F10 medium ("Sigma", USA) that contains $5 \%$ of fetal calf serum ("Gibko", USA) in the atmosphere of $5 \% \mathrm{CO}_{2}$ at $37^{\circ} \mathrm{C}$ up to titre of $5 \times 10^{5}$ cells per ml.

Quantity of live cells was evaluated by means of staining with $0.3 \%$ tripan blue solution and further examinations were carried out at the amount of live cells no less than $90 \%$.

It is important to estimate genotoxic effects of tested vaccines in immunization doses for assessment of their biosafety. Therefore, the content of preparation in the samples was determined as a dose recommended by producers per $1 \mathrm{~kg}$ of animal weight. This provides the same content of the preparation in 1 litre of incubation medium containing the cells of tested culture.

Complex preparations of veterinary vaccines in tradable forms, containing one dose per each packing unit, were studied.

CHO-K1 and Vero cells were used as the positive control after treating with $0.1 \mathrm{mM} \quad \mathrm{N}$ nitrosomethylurea during $48 \mathrm{~h}$.

Intact (untreated) cells of CHO-K1 and Vero cultures grown at $37^{\circ} \mathrm{C}$ during $24 \mathrm{~h}$ up to titre of $5 \times 10^{5}$ cells per $\mathrm{ml}$ were used as a negative control. The cells of negative control, suspended in nutritive medium in the volume equivalent to that for a positive control, were added to agarose gel for immobilization.

Quantity of live cells in the positive and negative controls was determined by staining with $0.3 \%$ tripan blue.

Cell suspension in incubating medium was mixed with the sample of certain preparation in concentration, providing immune response, and then incubated during $24 \mathrm{~h}$ at $37{ }^{\circ} \mathrm{C}$ to reveal the genotoxic action of veterinary vaccine preparations.

Microsomal fraction S9 of rat liver in concentration of $5 \%$ in the incubation mixture was used in the experiments related with metabolic activation. Incubation period was $3-24 \mathrm{~h}$ at $37{ }^{\circ} \mathrm{C}$. 
$D N A$-degrading activity in the samples of veterinary vaccines

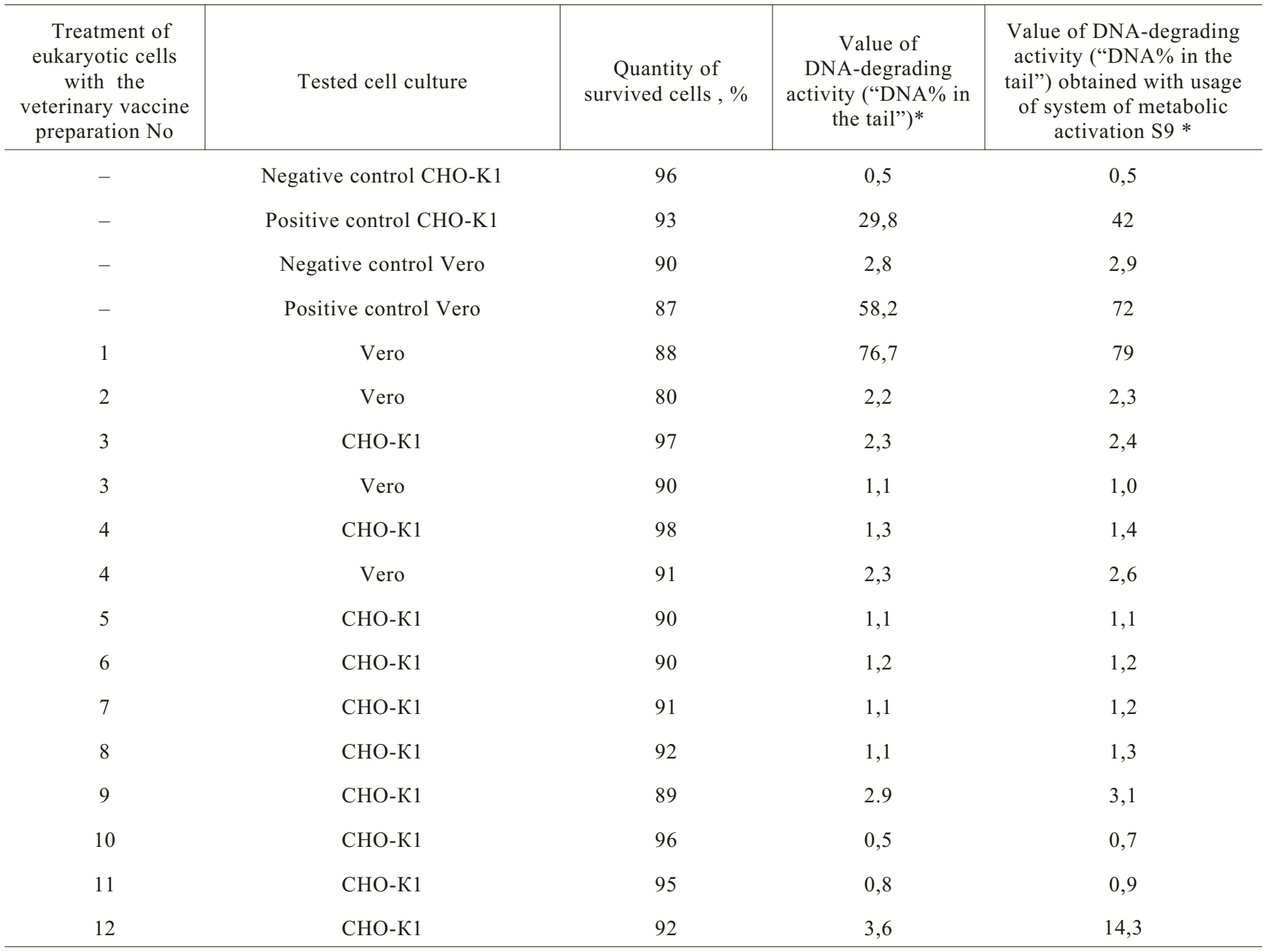

* - results are significant at $\mathrm{p}<0.05$.

Genotoxic properties of veterinary vaccines were analyzed using the following scheme: gel-slide preparation, micropreparation forming, lysis, alkaline denaturation, electrophoresis, neutralization/fixation, preparation staining by acridine orange, microscopic analysis.

Microscopy study of micropreparation was performed using fluorescent microscope ("LUMAM P8", Russian Federation). No less than 100 "DNA-comets" were analysed for each micropreparation.

Computer processing of digital images was made by means of program "CASP"-Comet Assay Software Project http://www.casp.of.p1 (freeware). Such parameters of "comets" as "tail length", "DNA\% in the tail", "tail moment" etc. were determined.
Statistical analysis of results was performed for each experimental point. Indicators of DNA damage in experimental and control groups were estimated using Dannet criterion. Statistically significant effect serves as a measure of positive result.

Results and discussion. We have obtained the characteristics of DNA-degrading activity of both veterinary vaccines and control samples using DNA-Comet assay for determination of their genotoxic properties in the cultures of eukaryotic cells $\mathrm{CHO}-\mathrm{K} 1$ and Vero (see table).

Using alkaline gel-electrophoresis of isolated cells (DNA comets) the electrophoretic tracks of "comet" type were obtained in the samples of positive control (cell cultures CHO-K1 and Vero, treated with 


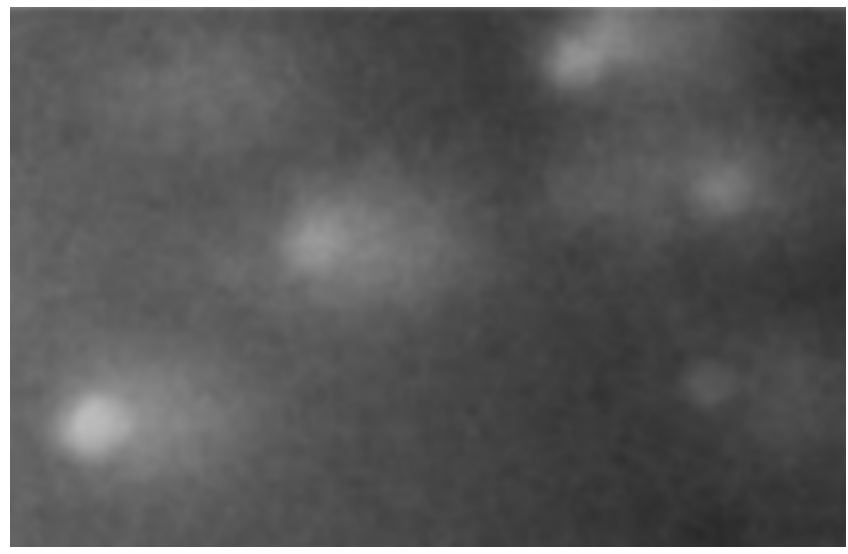

Fig.1. Electrophoretic images of DNA-comet tracks of positive control - CHO-K1 cells, treated with N-nitrosomethylurea.

$\mathrm{N}$-nitrosomethylurea) (Fig. 1). Such tracks were absent in the samples of negative control (cell cultures CHO-K1 and Vero, which were not treated with genotoxicants) (Fig. 2).

According to the data presented in the table the value of DNA lesion, "DNA \% in the tail", was $29.8 \%$ for the CHO-K1 cell line positive control, and $0.5 \%$ for negative one. The same electrophoretic profile was shown for the control samples of cell culture Vero; value of "DNA\% in the tail" was equal to $58.2 \%$ for the positive control and $2.8 \%$ for the negative one.

Studying genotoxic properties of veterinary vaccines by the DNA-Comet assay we have noticed that two samples reveal genotoxic action. Thus, DNA comets were shown on the electrophoretic images of DNA of cell culture Vero, treated with sample No 1 (vaccine against leptospirosis). Hereby, the value of "DNA \% in the tail" was $76.7 \%$ i.e. much higher than that for the positive control (Fig. 3, table).

Sample No 12 (inactivated vaccine against feline microspores) did not display genotoxic capacity toward cell culture $\mathrm{CHO}-\mathrm{K} 1$ under the standard condition of testing (the value of "DNA\% in the tail" was $3.6 \%$, i.e. approximately the same as in the negative control).

It was known [6] that the metabolites, formed in live organism as the products of biotransformation of potential genotoxicants, are able to reveal the genotoxicity themselves. Therefore, it seems reasonable to test veterinary vaccines in the system of metabolic activation using the microsomal fraction S9 from rat liver.

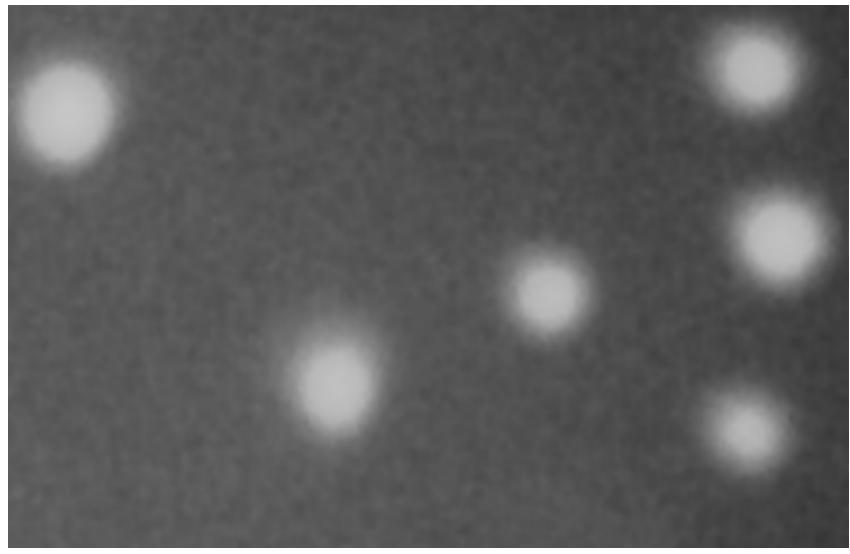

Fig.2. Electrophoretic images of DNA of negative control cells CHO-K1 cells, not treated with genotoxicants.

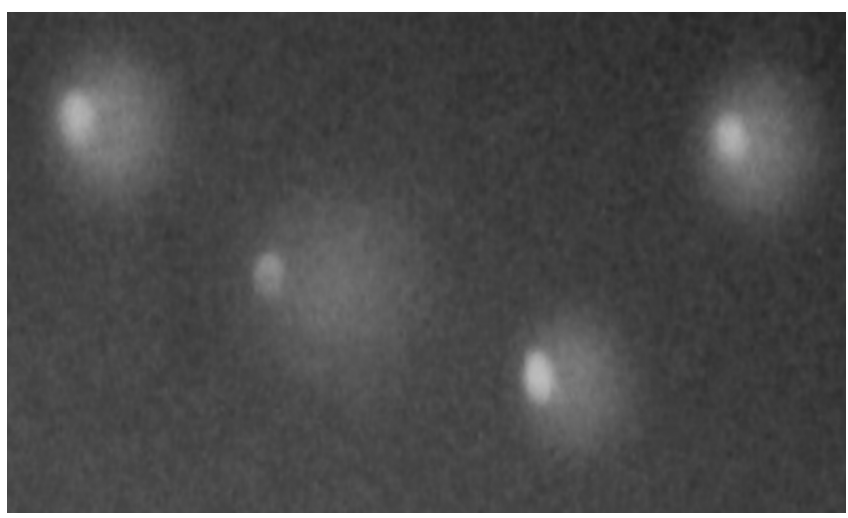

Fig. 3. Electrophoretic images of DNA of Vero culture cells, treated with sample No 1 (veterinary vaccine against leptospirosis).

Hence, electrophoretic images of DNA of cell culture CHO-K1 treated with sample No 12 (inactivated vaccine against feline microspores) demonstrated electrophoretic tracks of "comet" type under the conditions of metabolic activation. The value of "DNA\% in the tail" was $14.3 \%$ that was much higher in comparison with both the negative control $(0.5 \%)$ and the testing at standard conditions (3.6\%). However, the value of this characteristic appeared to be lower than that in the positive control $(29.8 \%)$. The obtained data indicated the presence of potential genotoxicants in the sample No 12 because the conditions of metabolic activation with S9 fraction simulated the metabolic processes that could occur in the organism and involve possible promutagens.

Other samples (No. from 2 to 11) did not reveal any genotoxic action on the cells of both types (CHO-K1 and Vero) either under the standard testing or under the 
condition of metabolic activation. The value of "DNA\% in the tail" did not exceed that for the negative control for all the preparations of veterinary vaccines mentioned above (see table).

Conclusions. The method of alkaline gel-electrophoresis of isolated cells (DNA-Comet assay) is suitable for the evaluation of genotoxic effects of veterinary vaccines on tested eukaryotic cells CHO-K1.

There are some advantages of this method such as quickness, low cost and high predictability of the results obtained.

The complex of experimental study performed allows us to recommend the assay for determination of biosafety of the veterinary vaccines preparations.

\section{С. М. Дибкова, М. С. Романько, Т. Г. Грузіна, Л. С. Рєзніченко, 3. Р. Ульберг, В. О. Уикалов, А. М. Головко}

Застосування методу ДНК-комет для визначення генотоксичності препаратів ветеринарних вакцин

Резюме

Мета. Вивчити можливість застосування методу лужного гель-електрофорезу (методу ДНК-комет) для визначення генотоксичних властивостей ветеринарних вакиин. Методи. Використано метод лужного гель-електрофорезу ізольованих еукаріотних клітин з наступною візуалізацією досліджуваних препаратів за допомогою флуоресиентної мікроскопії. Результати. Тестуванням ветеринарних вакиин методом ДНК-комет за лужних умов виявлено, щчо двом зразкам вакцин із 12 досліджених (№ 1 та № 12) притаманна генотоксична дія стосовно тестових еукаріотних клітин культур СНО-К1 $i$ Vero. При иььому зразок № 12 демонструє генотоксичні властивості лише за умови його тестування в системі метаболічної активації. Висновки. Метод лужного гель-електрофорезу ізольованих клітин (ДНК-комет) $є$ придатним для визначення генотоксичного впливу ветеринарних вакичин на тестові еукаріотні клітини СНО-К1. Перевагами пропонованого методу $\epsilon$ його експресність, низька вартість проведення досліджень $i$ висока прогностичність отриманих результатів. Виконаний комплекс експериментальних робіт дозволяє рекомендувати зазначений метод для характеристики біобезпеки препаратів ветеринарних вакичин.

Ключові слова: генотоксичність, ветеринарні вакиини, культури клітин, метод лужного гель-електрофорезу ізольованих клітин, біобезпека.

С. Н. Дыбкова, М. Е. Романько, Т. Г. Грузина, Л. С. Резниченко, 3. Р. Ульберг, В. А. Ушкалов, А. М. Головко

Применение метода ДНК-комет для определения генотоксичности препаратов ветеринарных вакцин

Резюме

Цель. Изучить возможность использования метода щелочного гель-электрофореза (метода ДНК-комет) для определения генотоксических свойств ветеринарных вакцин. Методы.
Использован метод щелочного гель-электрофореза изолированных эукариотных клеток с последующей визуализаичией исследуемых препаратов с помощью флуоресцентной микро- скопии. Результаты. Тестированием ветеринарных вакиин методом ДНК-комет в шелочных условиях выявлено, что препараты вакцин № 1 и № 12 из 12 исследованных обладают генотоксическим действием на тестовые эукариотные клетки культур СНО-К1 и Vего, причем препарат № 12 демонстрирует генотоксические свойства только при тестировании в системе метаболической активации. Выводы. Метод щелочного гель-электрофореза изолированных эукариотных клеток (ДНК-комет) пригоден для определения генотоксического влияния ветеринарных вакиин на тестовые эукариотные клетки СНО-К1. Преимуществами предлагаемого метода является его экспрессность, низкая стоимость выполнения исследований $u$ высокая прогностичность полученных результатов. Выполненный комплекс экспериментальных работ позволяет рекомендовать этот метод для характеристики биобезопасности препаратов ветеринарних вакцин.

Ключевые слова: генотоксичность, ветеринарные вакиины, культура клеток, метод щелочного гель-электрофореза изолированных клеток, биобезопасность.

\section{REFERENCES}

1. Collins A. R. The comet assay for DNA damage and repair: principles, applications and limitations // Mol. Biotechnol.-2004.-26, N 3.-P. 249-261.

2. Methods in molecular biology. In situ detection of DNA damage. Methods and protocols / Ed. V. V. Didenko.-Totowa: Humana press, 2002.-Vol. 203.-279 p.

3. Henderson L., Wolfreys A., Fedyk J., Bourner C., Windebank $S$. The ability of the Comet assay to discriminate between genotoxins and cytotoxins // Mutagenesis.-1998.-13, N 1.P. 89-94.

4. Tice R. R., Aqurell E., Anderson D. Single cell gel/comet assay: guadelines for in vitro and in vivo genetic toxicology testing // Environmen. and Mol. Mutagen.-2000.-35, N 3.P. 206-221.

5. Olive P. L. The comet assay: An overview of techniques // Meth. Mol. Biol.-2002.-203.-P. 179-194.

6. Application of alkaline gel electrophoresis of isolated cells to assess the genotoxic properties of natural and synthetic compounds: Methodical recommendations.-Moscow, 2006.$27 \mathrm{p}$.

7. Singh N. P., McCoy M. T., Tice R. R., Schneide E. L. A simple technique for quantitation of low levels of DNA damage in individual cells // Exp. Cell Res.-1988.-175, N 1.-P. 184-191

8. Lakin G. F. Biometrics: Appliances for biol. special. institute $/ 4^{\text {th }}$ ed.-Moscow: High school, 1990.-352 p.

UDC. 577.151:579.864.1 Received 30.10.09 